\title{
Climatic Changes and Household Food Availability in Malaysian East Coast Economic Region
}

\author{
Md. Mahmudul Alam* \\ Senior Lecturer \\ School of Economics, Finance \& Banking \\ College of Business, Universiti Utara Malaysia \\ Kedah, Malaysia \\ E-mail: rony000@ gmail.com \\ Tel: +601-62799091 \\ Chamhuri Siwar \\ Emeritus Professor \\ Institute for Environment and Development (LESTARI) \\ National University of Malaysia (UKM) \\ 43600 UKM Bangi, Selangor Darul Ehsan, Malaysia \\ E-mail: csiwar@ukm.my \\ Abdul Hamid Jaafar \\ Professor \\ Faculty of Economics and Management \\ National University of Malaysia (UKM) \\ 43600 UKM Bangi, Selangor Darul Ehsan, Malaysia \\ E-mail: ahamid@ukm.my \\ Basri Abdul Talib \\ Associate Professor \\ Faculty of Economics and Management \\ National University of Malaysia (UKM) \\ 43600 UKM Bangi, Selangor Darul Ehsan, Malaysia \\ E-mail: basri@ukm.my \\ *corresponding author
}

\section{Citation Reference:}

Alam, M.M., Siwar, C., Jaafar, A.H., and Talib, B. 2016. Climatic Changes and Household Food Availability in Malaysian East Coast Economic Region. Journal of Developing Areas. Vol. 50(5), pp.143 - 155. [Online Link]

This is a pre-publication copy.

The published article is copyrighted by the publisher of the journal. 


\title{
CLIMATIC CHANGES AND HOUSEHOLD FOOD AVAILABILITY IN MALAYSIAN EAST COAST ECONOMIC REGION
}

\author{
Md. Mahmudul Alam* \\ Universiti Utara Malaysia, Malaysia \\ Chamhuri Siwar \\ Abdul Hamid Jaafar \\ Basri Talib \\ Universiti Kebangsaan Malaysia, Malaysia
}

\begin{abstract}
Sustainable food security at household level is one of the emerging issues for all nations. There are several factors such as social, economic, political, demographic, natural, and livelihood strategies that causes to the vulnerability of the status of household food security. Therefore examining the vulnerability of these factors is essential to identify the reason and recognize the most vulnerable communities. This study is an attempt to study on the vulnerability of the factors of household food availability and its linkage with climatic changes in Malaysia. The study is based on primary data collected in the months of July - October, 2012 through a questionnaire survey on 460 low income households from East Coast Economic Region (ECER) in Malaysia. The samples were selected from $E$-Kasih poor household database, based on cluster random sampling technique. The study found that the vulnerability of the factors of household food availability has decreased statistically significantly over the last five years period in Malaysia for the factors of effectiveness of food distribution process, road and transportation facility for food distribution process, availability of expected food in the local market, sufficiency of expected food in the local market, and stability of food supply in market. The mean values of the current status of the factors of household food availability differ significantly at $1 \%$ significance level from the scenario of 5 years ago. However, most of the cases climatic issues were found less responsible for the changes of these factors. Though Malaysia is adversely affected by climatic change, the factors of food availability are not affected yet remarkably. This study suggests that the food security programs need to be integrated with climatic change adaptation programs to ensure more effective and sustainable household food security in future, especially among the poor and low income group. Moreover, a proper monitoring agency is required to ensure consistent supply of food in the rural and remote areas, especially at the time of natural calamity or off season.
\end{abstract}

JEL Classifications: I32, Q54, P48

Keywords: Climatic changes, Household food security, Food availability, Vulnerability, Poverty

Corresponding Author's Email Address: rony000@ gmail.com

\section{INTRODUCTION}

Food security is a critical global aspect of the individual and household wellbeing regardless of whether it is viewed locally, globally or within communities. Hunger and food insecurity are detrimental to the basic rights of a human being and are a prelude to problems including health, nutrition, and development. The household food security is a more current understanding of the food security concept. Most of the literature in this subject from the 1980s assumed national food security to be similar to food selfsufficiency and this poses a few challenges. According to Debebe (1995) household food security represents factors, which are linked to the actions of "...acquisition, household procurement strategies and socio-economic condition of the society." 
Various types of indicators are required to measure the many different aspects of food security at an individual, household, and country levels (Hoddinott, 1999). Various correlated environmental, socioeconomic, and political aspects that need multi-pronged approaches have an influence on food security (Debebe, 1995). Negatu (2006) suggested that one of the factors that have an effect on food security is land tenure insecurity and the other is not having accessibility to productive resources, low educational level, reduction in land holdings, not having accessibility to proper transport structure, low livestock productivity, unaware of suitable interventions, bad storage technology, and a high unemployment level. Other factors that also have an effect on food security include crop pests, drought, and sudden torrential rainfall, not having a draught oxen, increased population and shortage of land (Negatu, 2006).

Natural indicators result in specific higher variation in production costs and production that are linked to irrigation, infection and insecticide treatment and higher losses (Lovendal \& Knowles, 2006). Depending on the capability of traders bringing in food from various other areas and the available stock levels, this could potentially disrupt food supply and cause prices to increase further. The main environmental indicators prove to be trends and not shocks that occur. They negatively affect production through reduced soil fertility and lower yields as well as the rise of production cost per unit. The profitability of farming and the potential to gain income from other activities that are resource based are limited.

There are four dimensions of food security such as availability of food, stability of its supply, accessibility to food, and utilization of food. A vulnerable food system occurs when any dimensions of food security are insecure and uncertain. Understanding the vulnerability of the factors of food security can assist in the identification and comprehension of the fundamental dimension of a population's wellbeing and to recognize the most vulnerable communities in the regions or subgroups.

As like as other dimensions, household food availability is also very important for household food security that indicates sufficient quantities of suitable quality food supplied at household via local inputs or production. The kind of quality and quantity of food available in the market is dependent on the market's characteristics. The market infrastructure has an effect on food availability. As such, the market condition of various households from various infrastructure development places give rise to various levels of food availability. Thus, an important determinant of food security is the infrastructure access (Nyariki \& Wiggins, 1997). Similarly, Webb et al. (1992) and Negatu (2006) revealed that one of the reasons for the famine in Ethiopia is the isolation of the farming households from the major markets. Several factors that have an effect on the availability of household calories needs are such as the household's demography including household dependents like children and elders, gender of the head of household, education status of the household head and other household members (Iram \& Butt, 2004). Technology availability at the household level has an effect on the capacity of crop production, production conditions, and resources productivity. These involve availability and capability to utilize enhanced crop varieties, other aids like pesticides and fertilizers, and irrigation water in areas that are semi-arid (Nyariki \& Wiggins, 1997).

Malaysia is a very fast growing developing country. So, there are scopes of frequent changes in the macro variables that would affect food security. Moreover, the climatic factors are changing very rapidly in Malaysia and have been having adverse impacts on food production (Alam et al., 2011b; 2012a). Even, that household food insecurity is not only related to social and economic factors, but also statistically significantly linked to the direct and indirect impacts of climatic factors (Alam et al., 2016a). Previous studies showed that $50 \%$ or more of the low-income rural households face some level of food insecurity with $34.5 \%$ child hunger (Shariff \& Khor, 2008). The percentage of households with food insecurity in Malaysia is higher in urban low-income households, such as $66.6 \%$ (Zalilah, 1998) and $65.7 \%$ (Zalilah \& Ang, 2001) compared to rural low-income households 58\% (Shariff \& Khor, 2008). Another recent study showed that among the poor and low income household, $23.3 \%$ are mildly food insecure, $14.3 \%$ 
are moderately food insecure, and $9.6 \%$ are severely food insecure in Malaysia (Alam et al., 2016b).

Therefore, to understand the level of vulnerability of household food security, this study is an attempt to check food availability - one of the important dimensions of household food security, and its linkage with climatic changes in Malaysia.

\section{CLIMATE CHANGE AND HOUSEHOLD FOOD AVAILABILITY}

Climate changes affect the fundamental aspects of food production, which include water, soil, and biodiversity, negatively. In a broader viewpoint, it has an effect on all the four types of food security's dimensions (FAO, 2008). FAO also highlighted the impacts of the components of climatic changes on household food availability that are given in Table 1.

\section{TABLE 1: IMPACTS OF THE COMPONENTS OF CLIMATIC CHANGE ON HOUSEHOLD FOOD AVAILABILITY}

\section{COMPONENTS OF CLIMATE CHANGE}

$\mathrm{CO} 2$ fertilization effects

Increase in global mean temperatures

Gradual changes in precipitation (increase in the frequency, duration and intensity of dry spells and droughts)

Gradual changes in precipitation (changes in timing, location and amounts of rain and snowfall)

Gradual changes in precipitation (increase in the frequency, duration and intensity of dry spells and droughts)

Impacts of increase in the frequency and intensity of extreme weather events (increase in annual occurrence of high winds, heavy rains, storm surges, flash floods and rising water levels associated with tornados, tropical storms, and prolonged heavy rains)

\section{IMPACTS ON FOOD AVAILABILITY}

- Increased food production in major exporting countries would contribute to global food supply but diversion of land from food to more economically attractive cash crops could negate this benefit

- Reduced production of food crops and livestock products in affected areas

- Local losses could have temporary effect on local markets

- Reduction in global supplies likely to cause market prices to rise

- Declines in production

- Wild foods less available

- Pressure on grain reserves

- Decrease in food exports / increase in food imports

- Increased need for food aid

- Some local losses virtually certain, but their likely geographic distribution is not known

- Likely impact on global supplies, trade and world market prices is not known

- Declines in production; Wild foods less available - Pressure on grain reserves

- Decrease in food exports / increase in food imports

- Increased need for food aid

- Possible decrease in surplus production in flooded agricultural areas

- Increased need for emergency distribution of food rations 
Impacts of greater weather variability

- Some local losses virtually certain, but their likely geographic distribution is not known

- Likely impact on global supplies, trade and world market prices is not known

Source: Compilation from Table 1: A, B, C.1, C.2, D, E (FAO, 2008)

In general, climate change is expected to cause the number of people at risk from hunger to grow (FAO, 2005). Most crops have yearly cycles, and with climate changes, especially with temperature and rainfall, the yields will fluctuate as well. It is therefore challenging to maintain a continuous food supply with seasonal production. Floods and droughts are a major threat to stability of food and could result in transitory and chronic food insecurities. Both these occurrences are anticipated to occur more frequently, intensely and with less predictability as a result of changes in the climate. Rural areas that depend on rainfall for their agriculture, the changes in the frequency and amount of rainfall in a particular season will trigger an unpredictable local food system production.

In the case of rural people who tend to produce a large portion of food for own consumption, the effects of climate change on food production may lower the availability to the extent that choices of allocation would have to be determined inside a household. Similar choices will be faced by the rural and urban non-farming low-income households whose incomes are below the poverty line due to the effects of climate change. Urbanization is a worldwide phenomenon and a large number of the growing population in the urban areas are considered poor (Ruel et al., 1998). Therefore, over time, the allocation problems due to climate change would potentially become more prevalent in the urban areas.

When climate affects the infrastructure through higher frequency of floods that damage the infrastructure or heat stress on roads, there are effects on food distribution, which has an impact on having access to markets to purchase or sell food by the people (Abdulai \& CroleRees, 2001). Extreme weather pattern changes will have an impact on the stability and accessibility of food supply. Studies pointed out that the growing trend of crop loss due to extreme occurrences will far outweigh the slight positive effects of an average rise in temperature (Easterling et al., 2007). In forest regions, it is estimated that there would be more risks of fires, wind damages, insect infestations and other forestrelated disturbances. The change in the number of extreme occurrences will most probably have serious repercussions on small farming communities and artisanal fishermen (Easterling et al., 2007). Loss of livelihood and food insecurity would increase further with cultivated land loss and fish nurseries through coastal erosion and inundation in low-lying regions (FAO, 2003a).

According to FAO, up to the year 2030, the effect of climate change on global crop production will only be slight. However, after that, widespread drops in the level and productivity potential of cropland could happen, and several of the worst effects would probably be in the present food-insecure regions in the sub-Saharan Africa, which have the least capability to adapt to climate change or to import more food to compensate for the loss (Fischer et al., 2001; FAO, 2003b: 358).

In case of Malaysia the rainfall may fluctuate from about $-30 \%$ to $+30 \%$ and the temperature is projected to rise by $0.3^{\circ} \mathrm{C}$ to $4.5^{\circ} \mathrm{C}$ due to high greenhouse gas emissions that will cause sea level to rise about $95 \mathrm{~cm}$ over a hundred year-period (NRS, 2001). Another projection by NAHRIM (2006) shows that maximum monthly precipitation will increase up to $51 \%$ in the states of Pahang, Kelantan and Terengganu, while the minimum precipitation will decrease ranging from $32 \%$ to $61 \%$ all over Peninsular Malaysia; the annual rainfall will increase up to $10 \%$ in Kelantan, Terengganu, Pahang and North West Coast, and decrease up to 5\% in Selangor and Johor. Moreover, here the variation of amount of rainfall is very high (Alam et al., 2011a). This variation of climatic factors will make the agricultural system vulnerable, reduce crop yield and cause drought in many areas and cultivation of some crops may not be any more possible. A study found that a $1 \%$ increase in temperature leads to $3.44 \%$ decrease in current paddy yield, 
and $.03 \%$ decrease in paddy yield in next season and a $1 \%$ increase in rainfall leads to $.12 \%$ decrease in current paddy yield, and $.21 \%$ decrease of paddy yield in next season (Alam et al., 2014). Since agriculture is heavily dependent on climatic conditions, changes in the climatic factors result in year-to-year and area-to-area variability of crop production which largely affects the social and economic sustainability of the farmers (Alam et al., 2011b).

\section{DATA AND METHODOLOGY}

\section{Data Collection}

Data for this study were collected through an extensive questionnaire survey at household level in East Coast Economic Region (ECER) in Malaysia. ECER is more than half of the Peninsular Malaysia with the area of about $66,000 \mathrm{sq} \mathrm{km}$ that covers the states Kelantan, Terengganu, Pahang, and Mersing in Johor (Figure 1). ECER is very crucial for two major reasons; (a) ECER is the most vulnerable area in Malaysia due to climatic changes and (b) the income level of this region is low and poverty rate is high that is an obstacle to achieve Vision 2020.

\section{FIGURE 1: LOCATION OF STUDY AREA (ECER-MALAYSIA)}

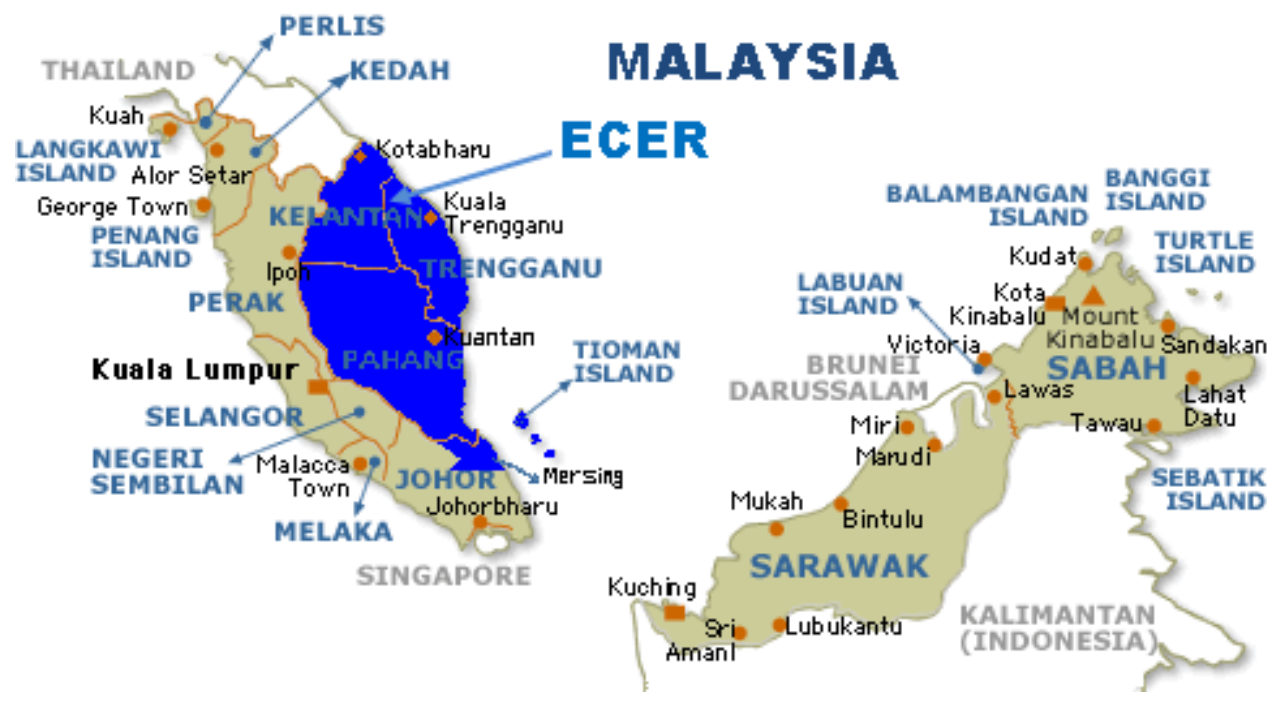

Source: Alam et al., $2012 b$

This study is based on primary data collected from 460 households in the urban and rural areas of ECER. The urban area of Kuantan and rural area of Pekan were selected from Pahang state. The urban area of Kota Bharu and rural area of Tumpat were chosen from Kelantan state. The urban area of Kuala Terengganu and rural area of Maring were taken from Terengganu state. A questionnaire guide technique was used to collect data. The survey was conducted by the regular enumerators of the Implementation Coordination Unit (ICU) from Pahang, Kelantan, and Terengganu states in the months of July-October, 2012. The survey followed the cluster random sampling technique. Initially the samples were clustered by location and then by poverty category. Finally, from each category, samples were picked up randomly from the E-Kasih database. $E$ Kasih system has been an integrated database system that has enlisted poor households at the national level to plan, implement, and monitor poverty programs in Malaysia.

\section{Variables and Statistical Analysis}


There are many factors relevant to the vulnerability of household food security due to climatic changes and non-climatic/general changes. To measure the degree of vulnerability of these factors, the perception of the households has been shown in two forms - using the scale of 1 (very low) to 5 (very high), and determine the changes by comparing current status with the scenario of 5 years ago. This study also checks the equality of two means between the current status of the relevant factors and five years earlier factors through ANOVA F statistics for Chi-Square $\left(\chi^{2}\right)$ Two Sample Test.

$$
\chi^{2}=\sum_{i=1}^{n} \frac{\left(O_{i}-E_{i}\right)^{2}}{E_{i}}
$$

Here, $\mathrm{O}_{\mathrm{i}}=$ Current Status of $i-$ th Factors (Ordinal Data)

$\mathrm{E}_{\mathrm{i}}=$ Previous Status of $i$ - th Factors (Ordinal Data)

The variables that are considered in this study are as follows:

X1 Effectiveness of food distribution process in Malaysia

X2 Road and transportation facility for food distribution process in Malaysia

X3 Availability of expected food in the local market in Malaysia

X4 Sufficiency of expected food in the local market in Malaysia

X5 Household food shortages due to unavailability of food in market

X6 Stability of food supply in market

\section{ANALYSIS AND DISCUSSIONS}

\section{Demographic Characteristics}

Among the respondents of the study, around $60 \%$ are selected from the urban area and $40 \%$ from the rural area. Male are the majority group, but the respondents represent the household data. The average age of all respondents is 50.7 years whereby male is 48.9 and female is 54.7. Most of the respondents have secondary education (46.5\%) followed by basic primary education (35.9\%). Among the total respondents, $72.8 \%$ are married whereas 3\% are unmarried. Most of the families (20.7\%) have 5 persons in the household and average family members are 5.6 persons per household. Among the respondents, most of the households (63.3\%) have no children (below 6 years) and average number of children (below 6 years) per household is 0.6 . Most of the households $(24.1 \%)$ have no school going children (below 6 years) and average number of school going children per household is 2.2 .

Among the households, $83.7 \%$ have their own residence. The respondents are engaged in various types of jobs, such as babysitter, batik designer, building contractor, small business, bus driver, canteen assistant, car service, carpenter, chief, clerk, cleaner, construction worker, craftsman, electrical technician, van driver, fisherman, fruit dealer, furniture shop, gardener, jewelry shop, hawker, daily labor, farmer, meson, painter, plumber, saloon worker, security guard, imam, teacher, government job, tailor, taxi driver, welding, factory labor, etc. In $90 \%$ of the cases, the heads of the households do not have any supplementary job. The rural households have more supplementary job options than urban households. The spouses of most of the households (88.3\%) are not engaged in a job. Around $76.3 \%$ of the households have only one earning member. At the household level, on an average, the earning family members to total family members ratio is 0.287 .

The household income of most of the respondents is between RM 501-1000 range. $35 \%$ of the household's monthly income is up to RM500 and 3.6\% household's income is above RM 2000. The per-capita income of 59.3\% of respondents is up to RM200. According to the survey findings, around 55\% are still poor and hard core poor. 
Around $9 \%$ of the people have an income of more than RM 400, who might be excluded in the low income group list soon. ${ }^{1}$ The distribution of income among the surveyed household is not so wide. However, here, the top $10 \%$ receive $23.2 \%$ of the total income while the bottom $10 \%$ receive only $3.4 \%$ of the income, and the top $20 \%$ receive $36.9 \%$ of the total income while the bottom $20 \%$ receive only $8.8 \%$. The degree of inequality is measured by Inequality Ratio, also known as Kuznets ratio. Here, the ratio is 1.624 if measured at household level and 1.405 is measured in terms of population. Among the respondents, around $82 \%$ do not have any savings. Therefore, any type of spike in regular life due to natural disasters, disease, crime, or social issues will push them towards borrowing. The rural households are less savings holders compared to urban households.

\section{Assessment of Vulnerability}

The changes in the effectiveness of food distribution process (X1) in Malaysia over the last five years are found statistically significant at $1 \%$ level (Table 3). However, only $47 \%$ of the respondents mention the change is positive and overall the average score increases from 2.65 to 3.39 (Table 2). It indicates that the vulnerability of the effectiveness of food distribution process in Malaysia has decreased over the time.

\section{TABLE 2: CLIMATIC INFLUENCES ON THE CHANGES IN FACTORS OF FOOD AVAILABILITY OVER THE FIVE YEARS PERIOD}

\begin{tabular}{|c|c|c|c|c|c|c|c|c|c|c|}
\hline \multirow[t]{2}{*}{ Issue } & \multirow[t]{2}{*}{ Time Frame } & \multicolumn{5}{|c|}{ Observation Scale* } & \multirow{2}{*}{$\begin{array}{c}\text { Average } \\
\text { value of } \\
\text { the } \\
\text { score }\end{array}$} & \multirow[t]{2}{*}{ S.D. } & \multirow{2}{*}{$\begin{array}{c}\text { Proportion } \\
\text { of High (4 } \\
\text { \& 5) } \\
\text { Observation }\end{array}$} & \multirow{2}{*}{$\begin{array}{c}\text { Proportion } \\
\text { of Low (1 \& } \\
2) \\
\text { Observation }\end{array}$} \\
\hline & & 1 & 2 & 3 & 4 & 5 & & & & \\
\hline \multirow[t]{3}{*}{$\mathrm{X} 1$} & Current scenario & 37 & 24 & 209 & 104 & 86 & 3.39 & 1.10 & $41.3 \%$ & $13.3 \%$ \\
\hline & 5 years ago & 91 & 70 & 217 & 72 & 10 & 2.65 & 1.03 & $17.8 \%$ & $35.0 \%$ \\
\hline & Climatic Influences & 320 & 34 & 90 & 15 & 1 & 1.57 & 0.93 & $3.5 \%$ & $77.0 \%$ \\
\hline \multirow[t]{3}{*}{$\mathrm{X} 2$} & Current scenario & 40 & 33 & 139 & 146 & 102 & 3.52 & 1.17 & $53.9 \%$ & $15.9 \%$ \\
\hline & 5 years ago & 62 & 115 & 185 & 96 & 2 & 2.70 & 0.96 & $21.3 \%$ & $38.5 \%$ \\
\hline & Climatic Influences & 289 & 25 & 125 & 20 & 1 & 1.74 & 1.01 & $4.6 \%$ & $68.3 \%$ \\
\hline \multirow[t]{3}{*}{$\mathrm{X} 3$} & Current scenario & 34 & 15 & 127 & 207 & 77 & 3.60 & 1.04 & $61.7 \%$ & $10.7 \%$ \\
\hline & 5 years ago & 49 & 109 & 204 & 95 & 3 & 2.77 & 0.92 & $21.3 \%$ & $34.3 \%$ \\
\hline & Climatic Influences & 323 & 46 & 76 & 15 & 0 & 1.53 & 0.88 & $3.3 \%$ & $80.2 \%$ \\
\hline \multirow[t]{3}{*}{$\mathrm{X} 4$} & Current scenario & 19 & 16 & 169 & 187 & 69 & 3.59 & 0.93 & $55.7 \%$ & $7.6 \%$ \\
\hline & 5 years ago & 40 & 99 & 206 & 106 & 9 & 2.88 & 0.93 & $25.0 \%$ & $30.2 \%$ \\
\hline & Climatic Influences & 308 & 47 & 87 & 17 & 0 & 1.60 & 0.94 & $3.7 \%$ & $77.2 \%$ \\
\hline \multirow[t]{3}{*}{ X5 } & Current scenario & 126 & 68 & 196 & 61 & 9 & 2.48 & 1.09 & $15.2 \%$ & $42.2 \%$ \\
\hline & 5 years ago & 138 & 138 & 157 & 24 & 3 & 2.17 & 0.94 & $5.9 \%$ & $60.0 \%$ \\
\hline & Climatic Influences & 316 & 44 & 76 & 22 & 2 & 1.59 & 0.96 & $5.2 \%$ & $78.3 \%$ \\
\hline \multirow[t]{3}{*}{ X6 } & Current scenario & 29 & 86 & 242 & 67 & 36 & 2.99 & 0.95 & $22.4 \%$ & $25.0 \%$ \\
\hline & 5 years ago & 39 & 131 & 253 & 28 & 9 & 2.65 & 0.80 & $8.0 \%$ & $37.0 \%$ \\
\hline & Climatic Influences & 341 & 33 & 73 & 13 & 0 & 1.47 & 0.86 & $2.8 \%$ & $81.3 \%$ \\
\hline
\end{tabular}

*Scale: $1=$ Very Low, 2=Low, 3= Normal, 4= High, 5= Very High

TABLE 3: STATISTICAL SIGNIFICANCE OF THE CHANGES IN THE FACTORS OF FOOD AVAILABILITY OVER THE FIVE YEARS PERIOD 


\begin{tabular}{lllll} 
Issue & \multicolumn{3}{c}{ Changes over last five years } & \multicolumn{1}{l}{$\begin{array}{l}\text { Chi-Square } \\
\text { Value }\end{array}$} \\
X1 & Decrease & Same & Increase & \\
X2 & $24(5.2 \%)$ & $220(47.8 \%)$ & $216(47 \%)$ & $295.2^{*}$ \\
X3 & $27(5.9 \%)$ & $186(40.4 \%)$ & $247(53.7 \%)$ & $406.5^{*}$ \\
X4 & $17(3.7 \%)$ & $191(41.5 \%)$ & $252(54.8 \%)$ & $382.1^{*}$ \\
X5 & $26(5.7 \%)$ & $215(46.7 \%)$ & $219(47.6 \%)$ & $294.9^{*}$ \\
X6 & $37(8 \%)$ & $279(60.7 \%)$ & $144(31.3 \%)$ & $467.3^{*}$ \\
& $44(9.6 \%)$ & $266(57.8 \%)$ & $150(32.6 \%)$ & $388.5^{*}$ \\
$*$ Significant at 1\% level & & &
\end{tabular}

The changes in the road and transportation facility for food distribution process (X2) in Malaysia over the last five years are found statistically significant at $1 \%$ level (Table 3). However, 54\% of the respondents mention the change is positive and overall the average score increases from 2.7 to 3.52 (Table 2). It indicates that the road and transportation facility for food distribution process in Malaysia has decreased over the time. The changes in the availability of expected food in the local market (X3) in Malaysia over the last five years are found statistically significant at $1 \%$ level (Table 3 ). However, $55 \%$ of the respondents mention the change is positive and overall the average score increases from 2.77 to 3.6 (Table 2). It indicates that the vulnerability of availability of expected food in the local market in Malaysia has decreased over the time.

The changes in the sufficiency of expected food in the local market (X4) in Malaysia over the last five years are found statistically significant at $1 \%$ level (Table 3). However, only $48 \%$ of the respondents mention the change is positive and overall the average score increases from 2.9 to 3.6 (Table 2). It indicates that the vulnerability of availability of expected food in the local market in Malaysia has decreased over the time. The changes in the household food shortages due to unavailability of food in market (X5) over the last five years are found statistically significant at $1 \%$ level (Table 3 ). However, only $31.3 \%$ of the respondents mention the change is positive and overall the average score increases from 2.17 to 2.48 (Table 2). It indicates that the vulnerability of the household food shortages due to unavailability of food in market has increased over the time.

The changes in the stability of food supply in market (X6) over the last five years are found statistically significant at $1 \%$ level (Table 3 ). However, only $32.6 \%$ of the respondents mention the change is positive and overall the average score increases from 2.65 to 2.99 (Table 2). It indicates that the vulnerability of the stability of food supply in market has decreased over the time. For all of the cases, most of the respondents mention that the influences of climatic factors are low for the changes of these food availability factors over the five years time (Table 2).

\section{CONCLUSIONS}

The study found that the vulnerability of the factors of food availability has decreased statistically significantly over the last five years period in Malaysia, except the vulnerability of the factor of household food shortages due to unavailability of food in market. Though the score of this factor shows vulnerability has increased but majority of the respondents, around $68.7 \%$, mention the vulnerability has decreased.

The mean values of the current status of the factors of household food availability differ significantly at $1 \%$ significance level from the scenario of 5 years ago. However, most of the cases climatic issues were found less responsible for the changes of these factors. Though Malaysia is adversely affected by climatic change, the factors of food availability are not affected yet remarkably.

However, climate change is considered as one of the major potential threats for household food security in Malaysia. Therefore, to ensure sustainable household food 
security in Malaysia, design of food security programs must integrate climatic change into the picture, and food security approaches must recognize climate change as an important driver. This integration also increases household capacity to adapt to climatic change. At the same time, climate change adaptation approaches and strategies to reduce vulnerability to climate change also increases household food security. Moreover, there should be a proper monitoring body to ensure consistent supply of food in the rural and remote areas, especially at the time of natural calamity or off season.

\section{ACKNOWLEDGEMENT}

We are thankful to Ministry of Science, Technology and Environment of the Government of Malaysia for generously funding the research, under the Fundamental Research Grant Scheme of the Malaysian Ministry of Higher Education (FRGS/1/2012/SS07/UKM/01/3) and UKM Arus Perdana Research Grant Project (AP-2014-017).

\section{ENDNOTE}

1. The hardcore poor are considered those with Ringgit Malaysia (RM) 0-110 income per person per month, for the rural area and RM 0-120 RM per person per month, for the urban area. The poor are considered those with RM 111-185 income per person per month, for the rural area and RM 121-200 per person per month, for the urban area. The recently and previously marginally non-poor (mudah miskin and terkeluar) are more than RM 185, per person per month, for the rural area and RM 200, per person per month, for the urban area.

\section{REFERENCES}

Abdulai, A. \& CroleRees, A. 2001. Constraints to income diversification strategies: Evidence from Southern Mali. Food Policy 26(4): 437-452.

Alam, M.M., Toriman, M.E., Siwar, C., \& Talib, B. 2011a. Rainfall variation and changing pattern of agricultural cycle. American Journal of Environmental Sciences 7(1): 82-89.

Alam M.M., Siwar, C., Murad, M.W., \& Toriman, M.E. 2011b. Farm level assessment of climate change, agriculture and food security issues in Malaysia. World Applied Sciences Journal 14(3): 431-442.

Alam, M.M., Siwar, C., Mohd Ekhwan, T., Molla, R.I., \& Talib, B.A. 2012a. Climate Change Induced Adaptation by Paddy Farmers in Malaysia. Mitigation and Adaptation for Global Change 17(2): 173-186.

Alam, M.M., Morshed, G., Siwar, C. \& Murad, M.W. 2012b. Initiatives and Challenges of Agricultural Crop Sector in ECER Development Projects in Malaysia, American-Eurasian Journal of Agricultural \& Environmental Science 12(7): 922-931.

Alam, M.M., Siwar, C., Talib, B., \& Toriman, M.E. 2014. Impacts of Climatic Changes on Paddy Production in Malaysia: Micro Study on IADA at North West Selangor, Research Journal of Environmental and Earth Sciences 6(5): 251-258.

Alam, M.M., Talib, B., Siwar, C., \& Wahid, A.N.M. 2016a. Climate Change and Food Security of the Malayan East Coast Poor: A Path Modeling Approach. Journal of Economic Studies. Forthcoming. 
Alam, M.M., Siwar, C., Wahid, A.N.M., \& Talib, B. 2016b. Food Security and Low-Income Households in the Malaysian East Coast Economic Region: An Empirical Analysis. Review of Urban \& Regional Development Studies 28(1): 2-15.

Debebe, H. 1995. Food security: A brief review of concepts and indicators. In Multa, D., Wolday, A., Simeon, E. \& Tesfaye, Z. (ed.). Food security, nutrition and poverty alleviation in Ethiopia problems and prospects, pp.1-18. Addis Ababa: Agricultural Economics society of Ethiopia.

Easterling, W.E., Aggarwal, P.K., Batima, P., Brander, K.M., Erda, L., Howden, S.M., Kirilenko, A., Morton, J., Soussana, J-K., Schmidhuber, J. \& Tubiello , F.N. 2007. Food, Fibre and Forest Products. In Parry, M.L., Canziani, O.F., Palutikof, J.P., van der Linden, P.J. \& Hanson, C.E. (ed.). Climate change 2007: Impacts, adaptation and vulnerability. Contribution of working group II to the fourth assessment report of the intergovernmental panel on climate change, pp. 273-314. Cambridge: Cambridge University Press.

EIA. 2005. International energy annual $2005-\mathrm{CO}_{2}$ world carbon dioxide emissions from the consumption of coal, 1980-2006 (Million Metric Tons of Carbon Dioxide). USA: Energy Information Administration.

FAO. 2003a. Future Climate Change and Regional Fisheries: A Collaborative Analysis. FAO Fisheries Technical Paper No. 452. Rome: Food and Agriculture Organization of the United Nations.

FAO. 2003b. Impact of Climate Change on Food Security and Implications for Sustainable Food Production. Conference Committee on World Food Security, 12-16 May. Rome: Food and Agriculture Organization of the United Nations.

FAO. 2005. The State of Food Insecurity in the World 2005. Rome: Food and Agriculture Organization of the United Nations.

FAO. 2008. Climate Change and Food Security: A Framework Document. FAO inter-departmental working group on climate change. Rome: Food and Agriculture Organization of the United Nations.

Fischer, G., Shah, M., Tubiello, F.N. \& Velthuizen, H.V. 2005. Integrated assessment of global crop production. Philosophical Transactions of the Royal Society B 360: 2067-2083.

Hoddinott, J. 1999. Choosing outcome indicators of household food security. Washington DC: IFPRI.

Iram, U. \& Butt, M.S. 2004. Determinants of household food security: an empirical analysis for Pakistan. International Journal of Social Economics 31(8): 735766.

Lovendal, C.R. \& Knowles, M. 2006. Tomorrow's hunger: A framework for analysing vulnerability to food security, UNU- WIDER. Research Paper No, 2006/119.

NAHRIM (2006) Final Report: Study of the Impact of Climate Change on the hydrologic Regime and Water Resources of Peninsular Malaysia, National Hydraulic Research Institute of Malaysia (NAHRIM) and California Hydrologic Research Laboratory (CHRL), Malaysia.

Negatu, W. 2006. Determinants of small farm household food security: evidence from south Wollo, Ethiopia. Ethiopian Journal of Development Research 28(1): 1-29.

NRS (2001) National Response Strategies to Climate Change. Ministry of Science, Technology and the Environment, Malaysia.

Nyariki, D.M. \& Wiggins, S. 1997. Household food insecurity in Sub-Saharan Africa: Lesson from Kenya. British Food Journal 99(7): 249-262.

Ruel, M.T., Garrett, J., Morris, S., Maxwell, D., Oshaug, A., Engele, P., Menon, P., Slack, A. \& Haddad, L. 1998. Urban challenges to food and nutrition security: A review of food security, health and caregiving in the cities. Washington DC: IFPRI.

Shariff, Z.M. \& Khor, G.L. 2008. Household food insecurity and coping strategies in a poor rural community in Malaysia. Nutrition Research and Practice 2(1): 26-34. 
Webb, P., Braun, J.V. \& Yohannes. Y. 1992. Famine in Ethiopia - Policy Implication of the Coping Failure at National and Household Levels. Washington DC: International Food Policy Research Institute: Research Report 92.

Zalilah, M.S. 1998. Growth status determinants of school age children from primarily low-income households in the urban area of Kuala Lumpur, Malaysia: A focus on intra-household factors. PH.D Dissertation, Michigan State University of USA .

Zalilah, M.S. \& Ang, M. 2001. Assessment of food insecurity among low income households in Kuala Lumpur using the Radimer/ Cornell food insecurity instrument - A validation study. Malaysian Journal of Nutrition 7: 15-32. 